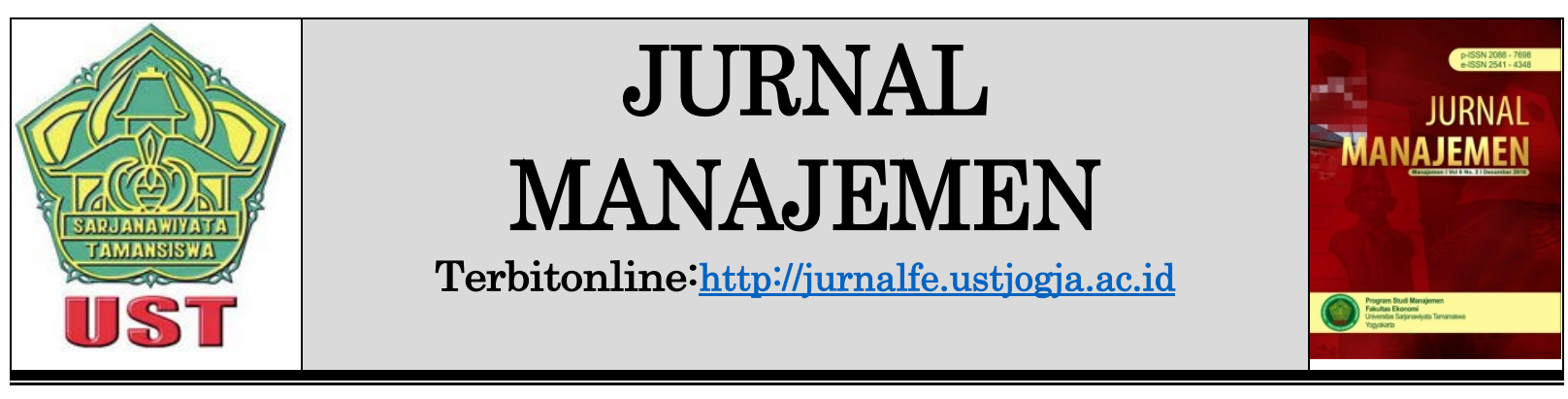

\title{
PENGARUH RASIO PROFITABILITAS TERHADAP NILAI PERUSAHAAN- PERUSAHAAN KELUARGA DI INDUSTRI RITEL
}

\author{
Hary S. Sundoro ${ }^{1}$ \\ Andreas Heryjanto 2 \\ 1,2Program Studi Manajemen, Fakultas Ilmu Sosial dan Humaniora, \\ Universitas Bunda Mulia
}

Korespondensi: hsundoro@bundamulia.ac.id

\begin{tabular}{lc}
\hline Informasi Naskah & \multicolumn{1}{c}{ Abstrak } \\
\hline Diterima: & The purpose of this research is to determine the \\
$25 \mathrm{Mei}$ & $\begin{array}{l}\text { effect of EPS, ROA, and ROE on changes in the value of } \\
\text { Revisi: }\end{array}$ \\
family retail companies. In addition, this research is \\
also expected to be able to answer the magnitude of the \\
Terbit: \\
influence of profitability ratios on changes in the value \\
28 Juni & $\begin{array}{c}\text { The rail companies. } \\
\text { Kata Kunci: Family }\end{array}$ \\
Business, PER, & $\begin{array}{l}\text { analysis which then the model used is Fixed Effect } \\
\text { Retail Industry. }\end{array}$ \\
& $\begin{array}{l}\text { Model (FEM). The results of this research show that } \\
\text { only EPS can be used as a variable on the value of retail } \\
\text { companies. Then profitability ratios can influence the } \\
\text { value of retail companies but not the most dominant } \\
\text { ones. }\end{array}$ \\
\hline
\end{tabular}

\section{PENDAHULUAN}

Pembahasan mengenai perusahaan keluarga telah menjadi sebuah fenomena yang menarik dalam dunia bisnis. Pengembangan dunia bisnis pada suatu negara telah mengandalkan perusahaan keluarga sebagai salah satu fundamental perekonomiannya. Berdasarkan data Badan Pusat Statistik, perusahaan keluarga di Indonesia merupakan perusahaan swasta yang mempunyai kontribusi besar terhadap Produk Domestik Bruto (PDB) yaitu mencapai 82,44\% (Halim, 2013). Perusahaan-perusahaan keluarga tersebut bergerak dalam berbagai macam industri, salah satunya yaitu di industri ritel. Dalam konteks global, potensi pasar ritel di Indonesia tergolong cukup besar. Industri ritel memiliki kontribusi terbesar kedua terhadap pembentukan PDB setelah industri pengolahan (Bank Indonesia, 2007). Perusahaan-perusahaan keluarga yang bergerak di indutri ritel pastinya 
harus memperhatikan kinerja mereka mengingat sudah banyaknya fenomena baru.

Perusahaan-perusahaan keluarga dari industri ritel yang telah terdaftar pada pasar modal dapat mengetahui kinerjanya dengan melihat nilai perusahaannya (Gitman dan Zutter, 2012). Nilai sebuah perusahaan dapat diukur dari Price Book Value (PBV) atau Price Earning Ratio (PER) (Sukamulja, 2004). Nilai PBV atau PER suatu perusahaan yang semakin tinggi dapat menunjukkan bahwa perusahaan tersebut semakin baik. Berarti, setiap perusahaan keluarga harus dapat meningkatkan PBV atau PER mereka. Nilai setiap perusahaan selalu mengalami perubahan. Perubahan nilai perusahaan tersebut dapat diketahui dengan melihat berbagai macam indikasi seperti rasio profitabilitas yang dapat terdiri dari Earning Per Share (EPS), Return On Assets (ROA) dan Return On Equity (ROE). Para stakeholders terutama manajemen internal di perusahaan keluarga dapat melihat indikasi perubahan dari EPS, ROA maupun ROE sehingga mereka dapat menetapkan kebijakan yang tepat dalam meningkatkan nilai perusahaan milik mereka.

Beberapa penelitian sebelumnya telah membahas pengaruh EPS, ROA dan ROE terhadap nilai perusahaan di berbagai macam industri. Har dan Ghafar (2015) meneliti pengaruh ROA dan ROE terhadap stock value perusahaan perkebunan di Malaysia. Begitu juga, Anwaar (2016) telah meneliti tentang pengaruh kinerja perusahaan terhadap nilai perusahaanperusahaan yang telah terdaftar di Bursa London. Hasil-hasil penelitian sebelumnya yang membahas pengaruh profitabilitas terhadap nilai perusahaan menunjukkan tingkat signifikansi yang berbeda-beda pula (Soliha dan Taswan, 2002; Sudiyatno, dkk, 2012; dan Yuanita, dkk, 2016). Dengan melihat fenomena bahwa perusahaan keluarga harus dapat meningkatkan nilai perusahaannya yang dapat diketahui berdasarkan pengaruh dari EPS, ROA dan ROE serta masih jarangnya penelitian yang membahas kinerja nilai sebuah perusahaan keluarga di industri ritel, maka penelitian ini akan membahas pengaruh profitabilitas terhadap nilai perusahaan. Namun, penelitian ini lebih fokus membahas pengaruh EPS, ROA dan ROE terhadap nilai perusahaan keluarga khususnya di industri ritel.

\section{KAJIAN PUSTAKA DAN HIPOTESIS}

Para stakeholders dapat menggunakan nilai perusahaan sebagai indikator terhadap kinerja suatu perusahaan. Menurut Sujoko dan Soebiantoro (2007) nilai perusahaan merupakan persepsi investor terhadap tingkat keberhasilan perusahaan yang terkait erat dengan harga sahamnya. Nilai perusahaan dapat diukur dengan beberapa metode (Weston dan Copeland, 2004) antara lain Price Earning Ratio (PER), Price Book Value (PBV), dan Tobin's q. Selanjutnya, penelitian ini akan menggunakan pengukuran nilai perusahaanperusahaan keluarga pada industri ritel dengan menggunakan Price Earning Ratio (PER). Pemilihan pengukuran nilai perusahaan dengan PER lebih disebabkan karena perhitungan PER memasukkan unsur laba bersih.

Menurut La Porta, dkk (1998), perusahaan dapat dikategorikan sebagai perusahaan keluarga jika perusahaan tersebut dimiliki oleh individu ataupun perusahaan tertutup (di atas 5\%) selama perusahaan tersebut tidak dimiliki 
oleh perusahaan publik, negara, ataupun institusi keuangan. Beberapa penelitian lain juga menggunakan persentase 5\% jika ingin mengkategorikan sebuah perusahaan sebagai perusahaan keluarga (Miller, dkk, 2007; dan Perez-Gonzalez, 2006).

Salah satu indikator yang dapat digunakan dalam menilai prospek perusahaan di masa depan adalah dengan melihat sejauh mana pertumbuhan profitabilitas perusahaan (Tandelilin, 2007). Artinya aspek profitabilitas sebuah perusahaan dapat digunakan sebagai peubah-peubah yang dapat memengaruhi nilai saham sebuah perusahaan. Rasio-rasio profitabilitas yang dapat digunakan dalam penelitian ini antara lain Return On Assets (ROA), Return On Equity (ROE) dan Earning Per Share (EPS). Menurut Kasmir (2012), ROA adalah suatu analisis untuk mengukur kemampuan perusahaan secara keseluruhan di dalam menghasilkan keuntungan dengan jumlah keseluruhan aktiva yang tersedia di dalam perusahaan. Dengan demikian, ROA dapat dijadikan salah satu faktor peubah terhadap nilai sebuah perusahaan. Beberapa penelitian sebelumnya pernah mengukur keabsahan pengaruh dari ROA terhadap nilai perusahaan (Soliha dan Taswan 2002; Menaje, 2012; dan Sudiyatno, dkk, 2012).

Return On Equity (ROE) merupakan suatu analisis untuk mengukur pengembalian yang diperoleh atas investasi pemegang saham biasa (Gitman dan Zutter, 2012). Menurut Yuanita, dkk (2016), ROE memiliki pengaruh positif terhadap nilai PBV pada perusahaan-perusahaan manufaktur yang sudah terdaftar di BEI. Penelitian lain yang dilakukan oleh Languju, dkk (2016) menemukan bahwa ROE berpengaruh positif terhadap nilai perusahaan. EPS (Earnings Per Share) dapat menunjukkan laba yang dihasilkan oleh setiap lembar saham biasa (Kieso, dkk, 2007). Semakin tinggi EPS, maka semakin tinggi besarnya laba yang tersedia untuk pemegang saham. Jatoi, dkk (2014) menyimpulkan bahwa EPS dari 13 perusahaan semen yang sudah terdaftar di bursa efek Pakistan memiliki pengaruh positif terhadap nilai perusahaan-perusahaan tersebut. Temuan lain oleh Harahap (2007) juga menemukan bahwa EPS dapat memengaruhi nilai perusahaan.

\section{Rerangka Pemikiran}

Penelitian ini dilakukan dengan tujuan untuk meramalkan pengaruh rasio profitabilitas yang terdiri dari ROA, ROE dan EPS terhadap nilai perusahaan-perusahaan keluarga di industri ritel. Untuk lebih jelasnya rerangka pemikiran penelitian ini dapat ditunjukkan seperti pada gambar 1 di bawah ini.

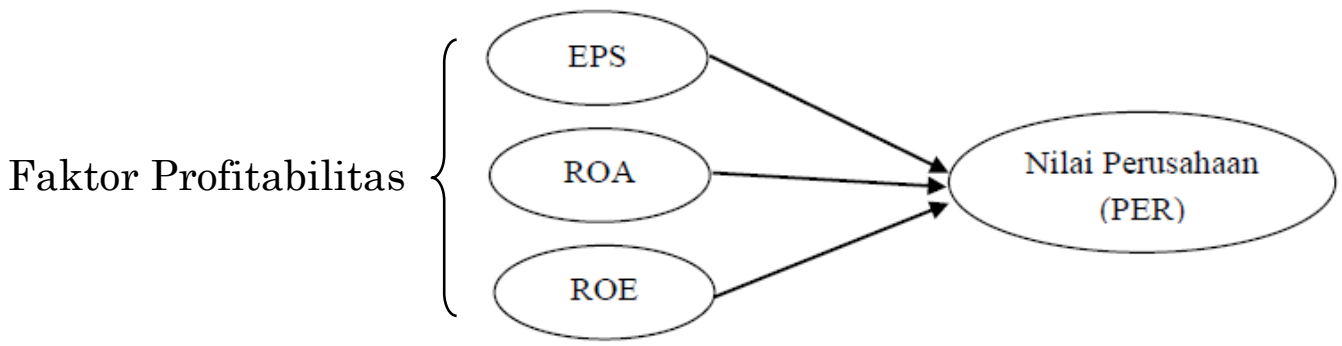

Gambar 1. Rerangka Pemikiran

Sumber: Peneliti, 2018 


\section{METODE PENELITIAN}

\section{Jenis dan Sumber Data}

Perusahaan keluarga pada penelitian ini adalah perusahaan yang sahamnya dimiliki oleh individu ataupun perusahaan tertutup di atas $5 \%$. Kemudian, industri ritel pada penelitian ini dibatasi hanya pada perusahaan yang bergerak di bisnis department store, super market, home appliance, dan mini mart. Kemudian sampel diseleksi lagi berdasarkan perusahaanperusahaan ritel keluarga yang telah go public dan mengalami pertumbuhan Earning After Tax (EAT) yang positif. Perusahaan-perusahaan keluarga di industri ritel yang dijadikan obyek penelitian ini antara lain: ACE Hardware, Alfa Midi, Alfamart, Matahari, PT. Mitra Adi Perkasa, Ramayana.

Jenis penelitian yang digunakan adalah penelitian kuantitatif. Sumber data yang digunakan dalam penelitian ini adalah data sekunder berupa data yang sudah dipublikasikan dan dapat diakses secara umum. Jenis datanya merupakan data panel yang merupakan kombinasi dari data time series dan cross-section. Rentang waktu (time series) pada penelitian ini dimulai dari tahun 2013 sampai dengan tahun 2017, sedangkan cross-section penelitian ini dilakukan antar nilai perusahaan-perusahaan keluarga di industri ritel.

Variabel gayut pada penelitian ini merupakan nilai perusahaanperusahaan keluarga yang bergerak di industri ritel. Kemudian, variabel bebas pada penelitian ini merupakan rasio profitabilitas yang dapat diwakili oleh ROA, ROE dan EPS. Data pada penelitian ini merupakan data sekunder yang berarti data pada variabel gayut mau pun variabel bebas di penelitian ini dapat dikumpulkan dari institusi-institusi yang sudah mempublikasikannya seperti dari website Bursa Efek Indonesia (BEI). Tabel 1 dapat menunjukkan sumber-sumber data untuk masing-masing variabel.

Dari tabel 1, satuan ukur pada data di semua variabel penelitian ini memiliki perbedaan. Beberapa variabel memiliki data dengan satuan persen, tetapi beberapa variabel lainnya memiliki data dengan satuannya dalam nominal. Oleh karena itu untuk menyamakan satuan ukur pada data di semua variabel penelitian ini, maka satuan ukur semua data diubah ke dalam satuan nominal supaya menyamakan dengan satuan variabel gayut di penelitian ini yaitu nilai saham (PER).

Tabel 1. Jenis Data, Simbol, Satuan dan Sumber Data

\begin{tabular}{lllll}
\hline No. & \multicolumn{1}{c}{ Jenis Variabel } & \multicolumn{1}{c}{ Simbol } & Satuan & \multicolumn{1}{c}{ Sumber Data } \\
\hline 1. & Nilai Perusahaan & PER & Nominal & BEI dan data \\
& & & & diolah \\
2. & ROA & ROA & Persen & BEI \\
3. & ROE & ROE & Persen & BEI \\
4. & EPS & EPS & Nominal & BEI \\
\hline
\end{tabular}

Sumber: BEI, 2018

\section{Alat Analisis}

Alat analisis yang digunakan pada penelitian ini yaitu dengan menggunakan metode regresi panel. Penelitian ini menggunakan metode regresi panel karena analisis akan dilakukan secara rentang waktu (time 
series) dan cross section. Secara umum, model persamaan regresi panel yang merupakan gabungan dari data time series dan cross section dapat dituliskan sebagai berikut (Nachrowi dan Usman, 2006):

$P E R_{i t}=\alpha+\beta R O A_{i t}+\beta R O E_{i t}+\beta E P S_{i t}+\varepsilon$

Keterangan:

$i \quad=1,2, \ldots, \mathrm{N}$

$t \quad=1,2, \ldots, \mathrm{T}$

$\alpha \quad=$ intercept $($ konstanta regresi)

$\beta \quad=$ slope (kemiringan garis regresi)

$\varepsilon \quad=$ error term

PER = Price Earning Ratio pada Perusahaan-Perusahaan Keluarga di Industri Ritel

ROA = Return On Assets pada Perusahaan-Perusahaan Keluarga di Industri Ritel

ROE = Return On Equity pada Perusahaan-Perusahaan Keluarga di Industri Ritel

EPS = Earning Per Share pada Perusahaan-Perusahaan Keluarga di Industri Ritel

Pada uji regresi panel dilakukan penentuan tiga model utama yaitu Common Effect Model, Fixed Effect Model, dan Random Effect Model (Gujarati, 2010). Pembahasan dengan menggunakan metode regresi panel akan menggunakan salah satu model dari tiga model utama. Oleh karena itu untuk memperoleh model panel data yang paling tepat, maka perlu dilakukan serangkaian pengujian secara ekonometrika. Untuk lebih jelasnya tahapan yang harus dilakukan dengan metode regresi panel dapat dilakukan dengan beberapa tahap berikut ini seperti gambar 2 .

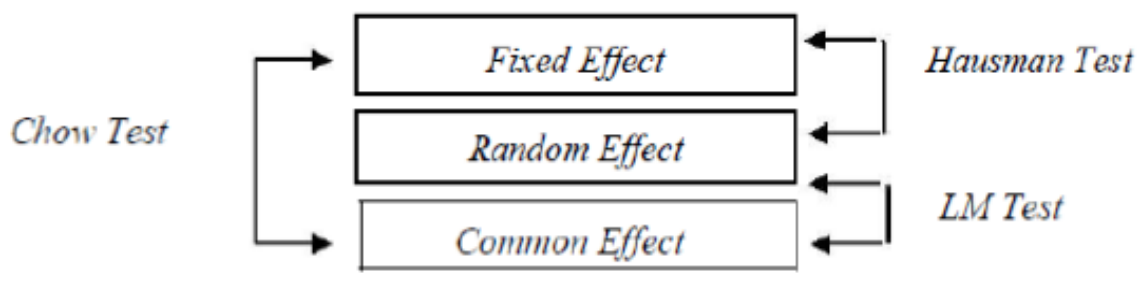

\section{Gambar 2. Tahap Model Regresi Panel}

Sumber: Gujarati, 2010

\section{HASIL DAN PEMBAHASAN}

Hasil dari pemilihan model regresi panel yang dapat dilakukan dengan uji Chow dan uji Hausman menunjukkan bahwa analisis data panel pada penelitian ini dapat dilakukan dengan Fixed Effect Model. Analisis regresi panel untuk penelitian ini dapat dilihat di tabel 2 .

Tabel 2. Hasil Analisis Regresi Panel dengan Fixed Effect Model

\begin{tabular}{ccccc}
\hline \hline Variable & Coefficient & Std. Error & t-Statistic & Prob. \\
\hline \hline C & 85.60839 & 30.75837 & 2.783255 & 0.0111
\end{tabular}




\begin{tabular}{lrlrl}
\multicolumn{1}{c}{ EPS? } & -0.169649 & 0.072103 & -2.352860 & 0.0285 \\
\multicolumn{1}{c}{ ROA? } & -206.3316 & 250.8118 & -0.822655 & 0.4199 \\
ROE? & 0.875604 & 3.245917 & 0.269756 & 0.7900 \\
\hline \hline R-squared & 0.602071 & Mean dependent var & 35.24200 \\
Adjusted R-squared & 0.450479 & S.D. dependent var & 30.04093 \\
S.E. of regression & 22.26925 & Akaike info criterion & 9.287615 \\
Sum squared resid & 10414.31 & Schwarz criterion & 9.707975 \\
Log likelihood & -130.3142 & Hannan-Quinn criter. & 9.422092 \\
F-statistic & 3.971653 & Durbin-Watson stat & 2.714254 \\
Prob(F-statistic) & 0.005282 & & \\
\hline \hline
\end{tabular}

Sumber: Peneliti, 2018

Tabel 2 dapat menunjukkan bahwa dari keseluruhan rasio profitabilitas yang terdapat pada penelitian ini hanya EPS yang dapat dijadikan sebagai peubah yang dapat memengaruhi nilai perusahaan-perusahaan ritel keluarga selama periode penelitian. Untuk ROA mau pun ROE tidak dapat mengindikasikan perubahan yang terjadi pada nilai perusahaan ritel keluarga. EPS memiliki nilai prob sebesar 0,0285 yang artinya lebih kecil daripada tingkat signifikansi 0,05. Tingkat koefisiensi EPS yang bernilai negatif dapat diartikan bahwa EPS memberikan pengaruh negatif terhadap perubahan nilai perusahaan-perusahaan ritel keluarga. Secara simultan rasio profitabilitas yang terdiri dari EPS, ROA dan ROE secara bersama-sama dapat memberikan pengaruh terhadap nilai perusahaan-perusahaan ritel keluarga sekitar $45 \%$ yang tercermin dari adjusted $R^{2}$. Sedangkan sisanya, peubah yang dapat memengaruhi nilai perusahaan-perusahaan ritel keluarga adalah faktor-faktor lain seperti fundamental makro ekonomi.

EPS dapat memengaruhi PER secara negatif sesuai dengan rumusan untuk mencari PER. Rumusan untuk menghitung PER yaitu harga saham dibagi dengan EPS (Gitman dan Zutter, 2012) yang artinya dengan semakin besar EPS maka nilai PER juga akan turut turun. Temuan ini juga sesuai dengan beberapa temuan sebelumnya yang menyatakan bahwa EPS dapat memengaruhi PER rasio secara negatif (Chang, dkk, 2008; De Wet, 2013; dan Rosikah, dkk, 2018). EPS merupakan acuan bagi investor untuk mendapatkan keuntungan dari saham yang dimilikinya. Namun demikian, keuntungan yang diperoleh setiap perusahaan belum tentu dibagikan kepada setiap investor justru lebih banyak dialihkan ke belanja modal. Dengan demikian harapan keuntungan yang semakin besar yang tercermin dari EPS menyebabkan harga pasar saham perusahaan tersebut semakin menurun yang akibatnya nilai perusahaan semakin menurun.

ROA dan ROE tidak dapat memengaruhi nilai perusahaan karena memiliki nilai prob masing-masing sebesar 0,4199 dan 0,79 yang artinya berada di atas tingkat signifikansi 0,05 . Hasil penelitian ini dilakukan selama periode 2013 sampai dengan 2017. Pada periode tersebut dapat diketahui bahwa metode belanja bagi kebanyakan konsumen di Indonesia telah berubah ke fase belanja secara online (BPS, 2018). Pembelanjaan secara online dapat memungkinkan konsumen untuk tidak hadir secara langsung ke toko-toko yang dimiliki perusahaan ritel keluarga tersebut. Minimnya belanja konsumen secara langsung ke toko-toko dapat mengindikasikan bahwa keseluruhan harta mau pun modal yang dimiliki oleh perusahaan ritel 
keluarga tersebut kurang dapat dimanfaatkan dalam mencari laba bagi mereka. Perhitungan ROA mau pun ROE mengutamakan pemberdayaan harta serta modal seperti toko-toko yang dimiliki, sehingga jika toko-toko tersebut tidak memberikan laba secara langsung maka sama saja ROA dan ROE bagi perusahaan ritel akan berdampak secara minim bagi laba mereka.

\section{PENUTUP}

\section{Simpulan}

Rasio profitabilitas dapat menyebabkan fluktuatif nilai perusahaan ritel keluarga namun bukan yang paling dominan, tetapi faktor lainnya yang dapat memberikan pengaruh terbesar. Faktor lain tersebut kemungkinannya adalah fundamental makro ekonomi. Dari keseluruhan rasio profitabilitas yang digunakan pada penelitian ini yang dapat memberikan pengaruh adalah EPS terhadap perubahan PER. Jika keuntungan yang diperoleh perusahaan sebagian besar dialokasikan untuk belanja modal dapat menyebabkan nilai perusahaan menurun.

Belanja online dapat menyebabkan aset tetap perusahaan ritel tidak diperdayagunakan secara optimal. Minat belanja konsumen Indonesia bukan berarti mengalami penurunan tetapi lebih beralih ke cara belanja secara online sehingga toko-toko yang dimiliki oleh perusahaan-perusahaan ritel tidak dapat dimanfaatkan secara optimal. Oleh karena itu ROA mau pun ROE kurang mampu dalam menjelaskan pergerakan nilai perusahaan ritel.

\section{Implikasi}

Pihak manajemen dari perusahaan-perusahaan ritel harus memperhatikan gejala makro untuk mendongkrak nilai perusahaan mereka. Rasio profitabilitas sudah tidak dapat digunakan sebagai peubah-peubah nilai perusahaan lagi untuk perusahaan industri ritel semenjak memasuki era online seperti sekarang. Perubahan nilai perusahaan akan lebih disebabkan oleh kondisi makro yang stabil sehingga hal tersebut dapat mendongkrak harga saham yang kemudian dapat turut meningkatkan nilai PER. Selain itu, mereka juga harus mulai memasuki ke penjualan secara online sehingga penjualannya tidak lagi hanya dilakukan melalui toko-toko mereka tetapi juga dapat dilakukan secara online.

Pihak investor juga harus melihat kondisi makro yang kemungkinan paling dapat memberikan pengaruh terhadap PER rasio perusahaanperusahaan ritel. Bagi pemerintah harus memperhatikan kestabilan ekonomi jika mereka juga turut prihatin akan kondisi perusahaan ritel keluarga. Apalagi industri ritel dan perusahaan keluarga merupakan salah satu sumber bagi GDP Indonesia, oleh karena itu jika kondisi ekonomi stabil maka nilai perusahaan-perusahaan ritel keluarga akan naik yang nantinya juga dapat menunjang kondisi perekonomian Indonesia.

\section{REFERENSI}

Anwaar, M. 2016. "Impact of Firms' Performance on Stock Returns (Evidence from Listed Companies of FTSE-100 Index London, UK". Global Journal of Management and Business Research: Accounting and Auditing, Vol 
16 Issue 1.

Bank Indonesia. 2007. Laporan Perekonomian Indonesia 2007. Jakarta: Bank Indonesia.

Chang, Chen, Su dan Chang. 2008. "The Relationship between Stock Price and EPS: Evidence Based on Taiwan Panel Data". Economics Bulletin, (3), 30. 1-12.

Gitman, L. J., dan Zutter, C. J. 2012. Principles of Managerial Finance, 13 ${ }^{\text {th }}$ edition. Edinburgh: Pearson.

Gujarati, D. N. 2010. Basic Econometrics $4^{\text {th }}$ edition. New York: Mc Graw Hill.

Halim, Y. 2013. "Analisa Suksesi Kepemimpinan pada Perusahaan Keluarga PT Fajar Artasari di Sidoarjo”. AGORA, Vol. 3 No 1.

Har, W. P., dan Ghafar, M. A. A. 2015. "The Impact of Accounting Earnings on Stock Returns: The Case of Malaysia's Plantation Industry". International Journal of Business and Management, Vol. 10 No 4.

Harahap, S. S. 2007. Teori Akuntansi. Jakarta: PT. Raja Grafindo Persada.

Jatoi, M. Z., Shabir, G., Hamad, N., Iqbal, N., dan Muhammad, K. 2014. "A Regressional Impact of Earning Per Share on Market Value of Share: A Case Study Cement Industry of Pakistan”. International Journal of Academic Research in Accounting, Finance and Management Service, Vol. 4 (4), 221-227.

JHvh De Wet. 2013. "Earnings Per Share as a Measure of Financial Performance: Does It Obscure More Than It Reveals?". Corporate Ownership and Control. Volume 10, Issue 4.

Kasmir. 2012. Analisis Laporan Keuangan. Jakarta: Rajawali Pers.

Kieso, D. E., Weygandt, J. J., dan Wardield, T. D. 2007. Akuntansi Intermediete edisi 12. Jakarta: Erlangga.

La Porta, R., De Silanes, F. L., Shleifer, A., dan Vishny, R.W. (1998). "Law and Finance". The Journal of Political Economy, Vol. 106 (6), 1113-1155.

Languju, O., Mangantar, M., dan Tasik, H. H. D. 2016. "Pengaruh Return On Equity, Ukuran Perusahaan, Price Earning Ratio dan Struktur Modal terhadap Nilai Perusahaan Property dan Real Estate Terdaftar di Bursa Efek Indonesia”. Jurnal Berkala Ilmiah Efisiensi, Vol. 16 (2), 387398.

Menaje, P. 2012. "Impact of Selected FinancialVariables on Share Prices of Publicly Listed Firms in the Philippines". American International Journal of Contemporary Research, Vol. 2 No. 9.

Miller, D., Miller., I. L. B., Lester, R. H., dan Cannella, A. A. 2007. "Are Family Firms Really Superior Performers?”. Journal of Corporate Finance, Vol. $13(5), 829-858$.

Nachrowi, D., dan Usman, H. 2006. Pendekatan Populer dan Praktis Ekonometrika untuk Analisis Ekonomi dan Keuangan. Jakarta: LP FE Universitas Indonesia.

Perez-Gonzalez, F. 2006. "Inherited Control and Firm Performance". American Economic Review, Vol. 96 (5), 1559-1588.

Rosikah., Prananingrum, D. K., Muthalib, D. A., Azis, M. I., dan Rohansyah, M. 2018. "Effects of Return on Asset, Return On Equity, Earning Per Share on Corporate Value". The International Journal of Engineering and Science, Volume 7, Issue 3, Pp. 06-14. 
Soliha, E., dan Taswan. 2002. "Pengaruh Kebijakan Hutang terhadap Nilai Perusahaan Serta Beberapa Faktor yang Mempengaruhinya". Jurnal Ekonomi dan Bisnis, STIE Stikubank Semarang: 1-18.

Sudiyatno, B., Puspitasari, E., dan Kartika, A. 2012. "The Company's Policy, Firm Performance, and Firm Value: An Empirical Research on Indonesia Stock Exchange". American International Journal of Contemporary Research, Vol. 2 (12), 30-40.

Sujoko dan Soebiantoro, U. 2007. "Pengaruh Struktur Kepemilikan Saham, Leverage, Faktor Interen dan Faktor Eksteren terhadap Nilai Perusahan”. Jurnal Manajemen dan Kewirausahaan. Vol 9, No. 1.

Sukamulja, S. 2004. "Good Corporate Governance di Sektor Keuangan: Dampak Good Corporate Governance Terhadap Kinerja Keuangan". Kinerja, Vol.8.No.1. (1-25).

Tandelilin, E. 2007. Analisis Investasi dan Manajemen. Portofolio edisi pertama, Yogyakarta: BPFE.

Weston J. F., dan Copeland E. T. 2004. Manajemen Keuangan. Edisi Sembilan Jakarta: Binarupa Aksara.

Yuanita., Budiyanto., dan Riyadi, S. 2016. "Influence of Capital Structure, Size and Growth on Profitability and Corporate Value". International Journal of Business and Finance Management Research, 80-101. 